\title{
EXPLORING IMPLICIT META-DISCOURSE IN LEGAL DISCOURSE, AN ANALYSIS OF THE CHINESE AND AMERICAN CONSTITUTIONS
}

\author{
Mengyu He' \\ Hajar Abdul Rahim ${ }^{2}$ \\ School of Humanities, Universiti Sains Malaysia, Malaysia \\ mengyuhe1989@gmail.com'; hajar@usm.my²
}

First received: 24 January 2017

Final proof received: 26 September 2017

\begin{abstract}
Research in meta-discourse, particularly explicit meta-discourse or meta-discourse markers has contributed much knowledge on the discourse features of specialised genres. However, there are very few studies on implicit meta-discourse. The current study explores implicit meta-discourse in legal discourse by comparing the implicit interpersonal meta-discourse in the Constitution of the People's Republic of China with the Constitution of the United States. The focus of the study is the use of implicit meta-discourse, particularly the grammatical meta-discourse in the legal discourse of two different languages and cultural groups. The findings demonstrate that there are similarities and differences in the use of implicit meta-discourse in the two constitutions. Within the context of language discourse, the findings of the current study suggest that legal discourse is distinctive in the use of implicit interpersonal meta-discourse, particularly in the way writers intrude into the discourse implicitly by certain key grammatical forms of meta-discourse. Despite the objectivity and rigour of legal discourse, the current study found that there is some level of subjectivity in such discourse, evident from the use of implicit meta-discourse.
\end{abstract}

Keywords: implicit meta-discourse; meta-discourse markers; legal discourse; interpersonal metadiscourse

Meta-discourse refers to the means by which writers organise a text, express their attitude, and establish a relationship with readers. It is an important means of conveying the information, building writer-reader interactions and facilitating understanding. Since its introduction by the structural linguist Zelig Harris (1959), there has been an increasing body of research in meta-discourse (e.g., Crismore, 1983; Vande Kopple, 1985; Beauvais, 1989; Ädel, 2006; Hyland, 2008; Kawase, 2015; Zhang, 2016; Jiang \& Hyland, 2016) which has contributed new knowledge and understanding regarding its use and function in discourse.

To date, studies on meta-discourse have focused largely on meta-discourse markers, which are also known as explicit meta-discourse. They are essentially explicit textual markers and have been analysed from different perspectives. Hopper (1981) used the term "meta-talk" to refer to explicit forms of meta-discourse and defined meta-discourse as explicit verbal properties of another message. The classifications of this type of explicit meta-discourse include metalinguistic referent (e.g., discourse deixis: there, here; demonstrative pronouns: this, that, etc.), metalinguistic operators (e.g., right, wrong, true, false, for example, etc.) and metalinguistic verbs (e.g., illocutionary acts of speech or verbs of saying: assert, say, tell, etc.). Beauvais' (1989) examination of meta-discourse based on speech act theory suggests that metadiscourse is the element in a sentence that conveys illocutionary contents in either fully or partially explicit form. In the sentence "I believe that education is necessary" for instance, the metadiscourse marker is "I believe that." It is an explicit form of meta-discourse because the performative verb "believe," when used in the first person present tense, performs an illocutionary act.

Meta-discourse is not only conveyed through overt and explicit performative sentences but also partially explicit meta-discourse markers, such as the adverbs, unfortunately, certainly, surprisingly, among others, which are also commonly found in the language. For instance, in the sentence "Unfortunately, some students don't have a good learning environment," the meta-discourse "unfortunately" is not attributed to a speaker. Hence, it is not completely overt and explicit. This point brings the discussion to Crismore's (1989) view that meta-discourse is a continuum, with explicit metadiscourse (overt meta-discourse and verbal metadiscourse) at one end and implicit meta-discourse (covert meta-discourse and grammatical metadiscourse) at the other.

Implicit meta-discourse markers are not as easy as explicit meta-discourse to be identified. This may be due to the concept of meta-discourse itself, which can be rather confusing because what is considered as a meta-discourse marker in one context may not be one in another. Crismore (1989) argued that it is difficult to be very explicit about metadiscourse theoretically, because speakers/writers in all 
spoken/written discourse may signal various dimensions of the communicative situation implicitly or explicitly. This suggests that implicit meta-discourse is also significant in making meaning and signalling speakers/writers' intent. Given this, the classification of meta-discourse must include both explicit and implicit markers and a theory of meta-discourse must consider the overt and covert continuum and its planes and show that all categories of meta-discourse are a matter of degree (Sangster, 1987).

Despite the significance of both types of metadiscourse, to date, studies on explicit meta-discourse markers significantly outnumber those on implicit meta-discourse. Implicit meta-discourse has only been analysed in a few studies (e.g., Crismore, 1983; Nagy, 1988; Tyler, 1988; Alyousef, 2015). These studies focused on a rhetorical theory of meta-discourse continuums (Crismore, 1983), subordinating clauses in personal communication texts (Nagy, 1988; Tyler, 1988) and implicit interactive and interactional markers in postgraduate Business student writing (Alyousef, 2015).

Besides the imbalance in the number of studies with regard to the two types of meta-discourse, the literature also shows that studies on meta-discourse have been limited to certain genres of texts, particularly the academic genre (e.g., Chafe \& Nicholas, 1986; Crismore, 1989; Hyland, 2000; Dahl, 2004; Del \& Milagros, 2011; McGrath \& Kuteeva, 2012). The interest in academic texts such as undergraduate essays, scientific discourse, and postgraduate dissertations lies in the fact that metadiscourse frequently occurs in academic discourse (Hyland, 2008).

Given the imbalance in the amount research in explicit and implicit meta-discourse and the focus on academic genre, the present knowledge of metadiscourse, particularly implicit meta-discourse, is therefore inadequate. This shortcoming is further compounded by the flexibility of the concept of meta-discourse, as an open category, to take in new items. Thus, to fully understand the categories of meta-discourse, there is a need for more studies on explicit and implicit meta-discourse in different genres. To this end, the current study focuses on legal discourse because meta-discourse in this genre is different from that of other types of discourse in application, distribution, and formation mechanism. Legal discourse is objective (Zhang, 2014). The distinct features of the types, quantity, and length of the linguistic form of meta-discourse in legal discourse allow for further analyses of the interpersonal features.

For a comprehensive analysis of metadiscourse in legal discourse, explicit and implicit aspects of meta-discourse should be given equal importance. The current study however focuses only on implicit meta-discourse because it has not received as much attention as explicit meta- discourse in the literature. Implicit meta-discourse markers are devices, which organise the discourse and express the writer's attitude by means of grammar (Zhang, 2013). Interpersonal metadiscourse is a type of implicit meta-discourse that enables writers to establish interpersonal relations and interact with their readers. Therefore, the investigation of interpersonal meta-discourse may be of great value in understanding the underlying interactions between writers and readers.

Besides focusing on implicit meta-discourse in legal discourse, the current study analysed texts in two linguistically and culturally different contexts, namely China and America. To date, there have been no attempts to compare the use of implicit meta-discourse in Chinese and English legal texts. Given this gap and assuming that implicit metadiscourse is used differently in legal texts written by different cultural groups, the current study compares the use of implicit meta-discourse in two comparable legal texts written in Chinese and English, namely the Constitution of the People's Republic of China (henceforth, PRC Constitution) and the Constitution of the United States of America (henceforth, U.S. Constitution).

As a country's supreme law, the constitution is important to both the country and its people, as it constitutes the basic tenets of nation building. It can be safely said that the PRC Constitution and the U.S. Constitution can be considered as legal discourse and the assumption of the study is that there is implicit meta-discourse in both constitutions. It is also reasonable to expect that the writers of the two constitutions establish interactions differently with their audiences due to linguistic and cultural differences. Given these considerations, the main objectives of the current study are to examine the types of implicit interpersonal meta-discourse in the PRC Constitution and the U.S. Constitution and to analyse the extent to which they are similar or different.

\section{Implicit Meta-discourse}

Hyland (2017) argued that "meta-discourse can be realised in a variety of ways," and "functions of meta-discourse may be performed in different ways" (p. 18). The grammatical forms of implicit metadiscourse tend to look to the Systemic Functional Grammar (SFG) (Halliday, 1976) for insights and theoretical support. Previous meta-discourse studies have mostly drawn on meta-functions in SFG (e.g., Vande Kopple, 1985, 2012; Crismore \& Farnsworth, 1990; Hyland, 2000). The recognition of metafunctions of language is based on three large networks, which are also the basis of descriptive grammar in SFG. According to Halliday and Matthiessen (2004), these networks are: "TRANSITIVITY (expresses representational meaning: what the clause is about, which typically some process is, with associated participants and 
circumstances, hence ideational), MOOD (expresses interactional meaning: what the clause is doing, as a verbal exchange between speaker/writer and audience, hence interpersonal), and THEME (expresses the organisation of the message: how the clause relates to the surrounding discourse, and to the context of situation in which it is being produced, hence textual)" (p. 309). Based on SFG, implicit meta-discourse is revealed through the analysis of three categories: textual grammatical meta-discourse (e.g., reference, substitution, ellipsis, etc.), interpersonal grammatical meta-discourse (e.g., intonation, mood, modality, etc.) and textual/interpersonal multi-functional grammatical meta-discourse (e.g. thematic structure, information structure, hypotaxis and parataxis, organisation of discourse, etc.) (Zhang, 2013, 2014).

Implicit meta-discourse in this study is principally in line with Hyland's analysis on metadiscourse. Also, following Hyland's (2008) view that any given linguistic item might realise more than one metadiscoursal function simultaneously, "textual, interpersonal, textual/interpersonal multifunctions" (Zhang, 2013, p. 134) may also be considered as implicit meta-discourse. This allows for a more comprehensive analysis of implicit metadiscourse devices in an under-explored area of legal discourse.

Interpersonal meta-discourse is an indicator of the attempts made by writers to create an interaction with their reader, reach their audience, and express their own truth-value judgments about the ongoing proposition (Reza, 2002). The current study focuses on a particular interpersonal meta-discourse, that is, grammatical interpersonal meta-discourse, which is realised through intonation, mood, and modality. These three linguistic elements are considered as interpersonal grammatical meta-discourse, as they represent non-propositional content and embody interpersonal function. They reflect the writer's use of language in interacting with other people, showing a kind of interpersonal function. For instance, modality involves "modalisation" which essentially refers to the scales of probability (how likely the proposition is true) and usuality (how often the proposition is true), and "modulation" which is the scales of obligation and inclination (Halliday, 2004, p. 618). This system "realises part of the interpersonal meta-function, and thus the appropriate use of modality is critical to successful communication between the speaker/writer and the listener/reader" (Yang, Zheng, \& Ge, 2015, p. 3). The intonation of a sentence could be traditionally classified as declarative, interrogative, and imperative. There is no obvious difference in intonation, mood, and modality, as the intonation would be changed with a different mood. For example, the declarative utterance could function differently depending on the intonation patterns. The types of intonation, mood, and modality therefore jointly shape writers' variegated intention and stance due to their concealed interpersonal function. In Chinese, modality is usually expressed by the modal verb, auxiliary and adverb; the mood is realised by the modal particle, repetition structure, and negative additional element; and intonation by the rise-fall tone with a different mood.

Textual/interpersonal multifunctional grammatical meta-discourse can be realised through the thematic structure, information structure, hypotaxis, parataxis, and organisation of discourse (Zhang, 2013). These strategies contain textual and interpersonal multi-functions. For example, the subordinator or coordinator in the sentence can either show how the text is connected or how the writer is performing the stance or attitude. In a coordinate construction, the writer begins with a critical examination of the more important topic and then decides to put forth the more important information first. The grammatical structure chosen by the writer indicates his or her attitude towards the information.

Combining SFG analysis with the model of implicit meta-discourse proposed by Zhang (2013, 2014), this exploratory study investigates the implicit interpersonal meta-discourse (i.e., interpersonal grammatical meta-discourse and textual/interpersonal multi-functional grammatical meta-discourse) in the Chinese and American constitutions. The objective writing style of legal discourse signals its writers' awareness of giving a precise proposition unaffected by the social personas. The choice of a particular interpersonal meta-discourse device reflects "the process of negotiating what is to be taken as accepted knowledge" (Hewings, 2006, p. 10) in legal discourse.

\section{MATERIALS AND METHODS \\ Materials}

To address the implicit meta-discourse in the PRC Constitution and U.S. Constitution, the two texts formed the corpus of the study. Comparability of the texts in terms of theme, style, and context of use is a crucial factor in the current study. In relation to this, it should be noted here that the PRC Constitution and the U.S. Constitution are similar in terms of the genre they belong to, i.e., legal discourse. However, there are differences in terms of content and structure due to their distinct political systems.

The current Constitution of the People's Republic of China was adopted by the fifth National People's Congress on December 4, 1982, with further revisions in 1988, 1993, 1999, and 2004. The Constitution has five sections, which are the preamble, general principles, fundamental rights and duties of citizens, structure of the state (which include the National People's Congress, the State Council, the Local People's Congress and Local 
People's Governments and the People's Courts and the People's Procuratorates), the national flag, and the emblems of the state (The National People's Congress, 1982). The Constitution of the United States is the supreme law of the United States of America. The Constitution has seven articles, which delineate the national frame of government. Its first three articles outline the doctrine of the separation of powers, whereby the federal government is divided into three branches: the legal, consisting of the bicameral Congress; the executive, consisting of the President; and the judicial, consisting of the Supreme Court and other federal courts. Articles Four, Five, and Six establish concepts of federalism, describing the rights and responsibilities of state governments and the states in relationship to the federal government. Article Seven underlines the procedure subsequently used by the thirteen States to ratify it (United States Senate, 1992). Both the documents are available in electronic format, accessible from the governments' official websites. PRC Constitution consists of 17,194 words (the English translation is taken from http://en.people.cn/constitution/constitution.html), while the U.S. Constitution comprises 8,076 words.

Meta-discourse research is also known as rhetorical analysis (Crismore, 1989; Hyland, 2008), and "selecting comparative texts for analysis is a vital component in contrastive rhetoric research" (Connor \& Moreno, 2005, p. 153). Given this,
Chapter Three of the PRC Constitution, i.e., "the structure of the state", which describes the legislative organisation in China and Article One of the U.S. Constitution, i.e., "the legislative branch", which describes the legislative structure in the America were selected for analysis. As the content is a key determiner of the rhetorical features (Peacock, 2002; Vassileva, 2000), the similarity of the subject matter facilitates the analysis of how writers construct meta-discourse in a similar content. Chapter Three of the PRC Constitution and Article One of the U.S. Constitution consist of 3,101 words and 2,372 words respectively.

\section{Methods}

Previous studies on meta-discourse divide metadiscourse into textual and interpersonal types (e.g., Vande Kopple, 1985); however, they cannot perform in isolation (Hyland, 2008). This study employs Zhang's $(2013,2014)$ taxonomy of implicit meta-discourse as the analytical framework (see Table 1). Zhang (2013, 2014) proposed a multifunctional meta-discourse which is textual/interpersonal multifunctional grammatical meta-discourse. The model builds on previous taxonomies and proposes a more comprehensive implicit meta-discourse framework. As Zhang's model has been established from a corpus of Chinese legal discourse, it is considered appropriate for the current study on legal discourse.

Table 1. The Classification of Implicit Interpersonal Meta-discourse following Zhang's $(2013,2014)$ Framework

\begin{tabular}{|c|c|c|c|c|}
\hline \multirow{4}{*}{$\begin{array}{l}\text { Main type } \\
\text { interpersonal } \\
\text { grammatical } \\
\text { meta-discourse }\end{array}$} & \multicolumn{3}{|l|}{ Subtype } & \multirow{2}{*}{$\begin{array}{l}\text { Descriptions } \\
\text { sentences which give a positive or affirmative sense }\end{array}$} \\
\hline & $\operatorname{mood}$ & \multicolumn{2}{|c|}{ affirmative declarative } & \\
\hline & & \multicolumn{2}{|c|}{ negative declarative } & sentences which give a negative meaning \\
\hline & & \multicolumn{2}{|l|}{ interrogative } & sentences which ask questions \\
\hline & & \multicolumn{2}{|l|}{ imperative } & $\begin{array}{l}\text { sentences which express orders, commands, requests, } \\
\text { advice, proposals or suggestions }\end{array}$ \\
\hline & \multirow[t]{4}{*}{ modality } & \multirow[t]{2}{*}{$\begin{array}{l}\text { propositional } \\
\text { (Palmer, 2001) }\end{array}$} & epistemic & $\begin{array}{l}\text { speakers make judgments about the factual status of } \\
\text { the proposition (e.g., I doubt that it rained yesterday.) }\end{array}$ \\
\hline & & & evidential & $\begin{array}{l}\text { speakers indicate what the evidence is that they have } \\
\text { for it (e.g., I heard that it rained yesterday.) }\end{array}$ \\
\hline & & \multirow[t]{2}{*}{ (Palmer, 2001) } & deontic & $\begin{array}{l}\text { relates to obligation or permission, emanating from } \\
\text { an external source (e.g., You must come in now.) }\end{array}$ \\
\hline & & & dynamic & $\begin{array}{l}\text { relates to ability or willingness, emanating from an } \\
\text { internal source (e.g., I will do it for you.) }\end{array}$ \\
\hline \multirow{7}{*}{$\begin{array}{l}\text { Textual/ } \\
\text { interpersonal } \\
\text { multifunctional } \\
\text { grammatical } \\
\text { meta-discourse }\end{array}$} & \multirow[t]{2}{*}{$\begin{array}{l}\text { thematic } \\
\text { structure }\end{array}$} & \multicolumn{2}{|l|}{ marked theme } & $\begin{array}{l}\text { signalled by predicating, preposing, clefting or } \\
\text { fronting of the theme and combination of these } \\
\text { options (Bell, 1991); tells one directly what a clause } \\
\text { is about (e.g., We could eat those berries.) }\end{array}$ \\
\hline & & \multicolumn{2}{|l|}{ unmarked theme } & $\begin{array}{l}\text { auxiliary in a closed interrogative (e.g., Did he buy a } \\
\text { new house?), Wh_element in open interrogative (e.g., } \\
\text { What did he house?) and predicator in an imperative } \\
\text { (e.g., Buy a new house!; Could eat those berries!) } \\
\text { (Bell, 1991) }\end{array}$ \\
\hline & \multirow{2}{*}{$\begin{array}{l}\text { information } \\
\text { structure }\end{array}$} & \multicolumn{2}{|l|}{ active voice } & the subject is doing the verb's action \\
\hline & & \multicolumn{2}{|l|}{ passive voice } & the subject is being acted upon by the verb \\
\hline & \multicolumn{3}{|l|}{ hypotaxis } & the subordination of one clause to another \\
\hline & \multicolumn{3}{|l|}{ parataxis } & $\begin{array}{l}\text { the placing of clauses or phrases one after another, } \\
\text { without words to indicate coordination or } \\
\text { subordination }\end{array}$ \\
\hline & \multicolumn{3}{|c|}{$\begin{array}{l}\text { organisation of discourse (also known as } \\
\text { 'visual meta-discourse') (Kumpf, 2000) }\end{array}$} & the way in which texts are set out \\
\hline
\end{tabular}


The analysis of implicit meta-discourse in the current study firstly involved identifying interpersonal meta-discourse items based on the categorisation of the two main types and 15 subtypes in Zhang's framework. Following this, the items were analysed quantitatively and qualitatively. The former involves determining the number of occurrences of interpersonal meta-discourse in Chapter Three of the PRC Constitution and Article One of U.S. Constitution, while the latter essentially requires an examination of how interpersonal metadiscourse is used for different purposes. The findings help to unravel the reasons for the differences and similarities in the use of metadiscourse in the two legal discourses.

\section{Data Analysis}

After downloading the PRC Constitution and the U.S. Constitution and selecting the texts for study, i.e., Chapter Three of the PRC Constitution and Article One of the U.S. Constitution, the data needed for analysis were collected. This firstly involved identifying and coding implicit interpersonal meta-discourse manually based on Zhang's (2013, 2014) classification of implicit meta-discourse in both texts. Then, the frequency of the types of interpersonal meta-discourse items in both texts was calculated. Once the frequency of each item was obtained, the percentage for each subtype was calculated by dividing the number of occurrences of each subtype by the total number of occurrences of the overall type and then multiplying the number by 100 . This was necessary to normalise the data because the total number of words in the two texts that were analysed is different.

To obtain the total number of instances for each interpersonal feature, coding was done manually and the frequency of occurrence was manually counted by referring to the context. Importantly, to investigate the frequency of interpersonal meta-discourse items in the selected texts, this study focuses on finding "an overall function for a sentence or clause" (Crismore \& Farnsworth, 1990). For example, the annotation of hypotaxis and parataxis relies on a complete sentence.

\section{RESULTS AND DISCUSSIONS}

The analysis revealed that grammatical metadiscourse is found in the two legal texts. This finding is consistent with the assumption that writers make use of implicit meta-discourse items in legal discourse (see Tables 2, 3, 4 and 5). Grammatical meta-discourse of affirmative, declarative, negative declarative, deontic modality, marked theme, unmarked theme, active voice, passive voice, hypotaxis, and parataxis are found in both texts. The analysis also shows that the U.S. Constitution text makes greater use of grammatical meta-discourse items compared to the PRC Constitution text. This is indeed an interesting and novel finding given the cultural context of the two texts.

The following sections present the findings of the current study on the use of grammatical metadiscourse in specific contexts and discuss the differences and similarities in the use of metadiscourse in the two texts that were analysed.

\section{Comparison of Mood}

The forms of mood are "the major interpersonal system of the clause" (Halliday \& Matthiessen, 2004, p. 97). For instance, the adoption of imperative mood assumes that the writer is giving commands. In relation to this, it is helpful to classify mood into subtypes of declarative (including affirmative declarative and negative declarative), interrogative, and imperative since the initial analysis of the constitutions suggested that some of these subtypes were noted in the writers' deployment. Table 2 presents an analysis of mood in the PRC Constitution (Chapter Three "the structure of the state") and the U.S. Constitution (Article One "the legislative branch").

Table 2. Mood in the PRC Constitution and the U.S. Constitution

\begin{tabular}{lcccc}
\hline \multirow{2}{*}{ Type of Mood } & \multicolumn{2}{c}{ PRC (chapter three) } & \multicolumn{2}{c}{ US (article one) } \\
\cline { 2 - 5 } & Freq. of MD & $\%$ & Freq. of MD & $\%$ \\
\hline Affirmative Declarative & 57 & 92 & 86 & 73 \\
\hline Negative Declarative & 5 & 8 & 32 & 27 \\
\hline Interrogative & 0 & 0 & 0 & 0 \\
\hline Imperative & 0 & 0 & 0 & 0 \\
\hline Total Number & $\mathbf{6 2}$ & $\mathbf{1 0 0}$ & $\mathbf{1 1 8}$ & $\mathbf{1 0 0}$ \\
\hline
\end{tabular}

$\mathrm{PRC}=$ PRC Constitution; US $=$ U.S. Constitution; $\mathrm{MD}=$ Meta-discourse; Freq. $=$ Frequency

The data in Table 2 suggest that both texts have declarative clauses but no interrogative and imperative clauses. More cases of affirmative declarative mood were identified in the PRC text.
However, there are much more instances of negative declarative mood in the US text. Some examples of the types are: 
1) 第五十九条

\section{全国人民代表大会由省、自治区、直辖市、特别行政区和军队选出的代表组成。各少数民族都应当有适} 当名额的代表。

\section{全国人民代表大会代表的选举由全国人民代表大会常务委员会主持。}

Translation (Article 59 The National People's Congress is composed of deputies elected from the provinces, autonomous regions, municipalities directly under the Central Government, and special administrative regions, and of deputies elected from the armed forces. All the minority nationalities are entitled to appropriate representation. Election of deputies to the National People's Congress is conducted by the Standing Committee of the National People's Congress.)

2) 第六十五条

全国人民代表大会常务委员会的组成人员不得担任国家行政机关、审判机关和检察机关的职务。Translatio n (Article 65 No one on the Standing Committee of the National People's Congress shall hold office in any of the administrative, judicial or procuratorial organs of the State.)

3) Section 3 - The Senate

No person shall be a Senator who shall not have attained to the Age of thirty Years, and been nine Years a Citizen of the United States, and who shall not, when elected, be an Inhabitant of that State for which he shall be chosen.

4) Section 5 - Membership, Rules, Journals, Adjournment

Neither House, during the Session of Congress, shall, without the Consent of the other, adjourn for more than three days, nor to any other Place than that in which the two Houses shall be sitting.

Example 1 shows that in the PRC text, the affirmative declarative mood is used to provide the relevant information of the National People's Congress, i.e., a sovereign organisation in China, including the composition of mechanism, the election of members, etc.

In the two constitutions, the negative declarative mood is mainly used to constrain individual rights, illegal behaviour, and ban anything that is prohibited in a country (see examples 2 and 3 ). It may be the case that the strategy of negative declarative mood is more formal and appropriate than imperative mood to pull readers along towards understandings of constitutions implicitly. However, the way of expressing negative declarative mood in the US text is more varied compared to the PRC text. Except for "Not", negative words such as "No", "Neither" are used at the beginning of a sentence in the US text (see example 4), which highlights the solemn and rigorous style of legal discourse.

\section{Modality}

Another prominent feature of the two constitutions is that writers deploy a large number of modal expressions to achieve the legislative intention and to regulate people's behaviour and social relationship. Modality is an important semantic category which operates at the sentence level. It is a cover term for devices which allow speakers to express varying degrees of commitment to or belief in a proposition. A simple definition of modality is that it is the space between "yes" and "no". By transmitting interpersonal function, modal systems allow speakers to signal stronger and weaker commitment to the factuality of statements.
According to Palmer (2001), modality is divided into propositional modality and event modality. Propositional modality includes epistemic and evidential modality, while event modality includes deontic and dynamic modality.

Epistemic modality is concerned with the speaker's knowledge, belief or attitude to the truth value or factual status of the proposition (Palmer, 2001). Epistemic modality is used in a situation that the speaker guesses or infers what he or she is not ascertaining. An epistemic modal reflects various judgments of factuality and expresses the possibility, probability, or impossibility of a particular proposition.

For example:

This could be our bus now; They would be very happy to meet you; You must be the bride's father; The bus should be here soon; It might freeze tonight; He will be home by now.

By using evidential modality, writers or speakers indicate the evidence they have for its factual status. Here is an example:

I see that she is coming. (evidential)

I guess that she is coming. (epistemic)

Deontic modality signals a speaker's judgments by showing how people should act or behave in the real world. Deontic modality is used in a situation that the speaker permits or demands the listener to do something. Deontic modality usually conveys two types of social information: obligation and permission.

For example:

You must take these books back; You should take these books back; You need to take these books back; You ought to take these books back. (obligation) 
You can leave them here; You could leave them here; You might leave them here. (permission)

Deontic modality is different from dynamic modality. Functionally, dynamic modals do not serve to position the speaker with respect to the propositional content of the utterance, but belong to the propositional content. For instance, deontic can means "permission", while dynamic can means not only "ability", but "possibility". Here are some examples:

You can go now. (deontic, I give permission)

He can run a mile in five minutes. (dynamic, ability)

He can escape. (dynamic, it is possible since the door is not locked.)

Palmer (2001) suggested that epistemic modality is concerned with the speculation and inference of the speaker, and the speaker's epistemic judgment; while deontic modality implies that the speaker has a certain power to deliver responsibility or duty to the listener.

With regard to various kinds of modality, different modal words have different values, which determine the meaning of the expression. According to Halliday (2004), the value of modality is divided into "advanced, intermediate and lower level" ( $\mathrm{p}$. 358). Advanced modality is expressed through must, ought to, be required to, need, have to, mustn't, oughtn't to, can't, mightn't, etc; the expression of intermediate modality includes will, would, should, shall, won't, wouldn't, shouldn't, shall not, etc. and the lower modals contain may, can, be allowed to, might, could, needn't, don't have to, etc. Peng (2000) divides Chinese modals into three levels based on Halliday's classification. Advanced modals in Chinese include应当 (yingdang), 应该 (yinggai), 必须(bixu), 务必 (wubi), 应 (ying), 要 (yao), 须要 (xuyao), 不可能 (bukeneng), 不可 (buke), 不能 (buneng), 不得 (bude), 不该 (bugai) etc.; intermediate modals include愿意 (yuanyi), 想 (xiang), 希望 (xiwang), 肯 (ken), 敢 (gan), 愿 (yuan), 不愿意 (buyuanyi), 不情愿 (buqingyuan), 不想 (buxiang), 不肯 (buken), etc. and the lower one contains 可能 (keneng), 会 (hui), 可以 (keyi), 能 (neng), 能够 (nenggou), 不会 (buhui), 不必 (bubi), 可能不 (kenengbu), 无须 (wuxu), 不须 (buxu), etc. (for English translations, please refer to the Appendix).

Table 3 shows the modality in the texts in the PRC Constitution and the U.S. Constitution that were analysed.

Table 3. Modality in the PRC Constitution and the U.S. Constitution

\begin{tabular}{|c|c|c|c|c|c|}
\hline \multirow[t]{2}{*}{ Modality } & & \multicolumn{2}{|c|}{ PRC (chapter three) } & \multicolumn{2}{|c|}{ US (article one) } \\
\hline & & Example & Freq \& \% & Example & Freq \& \% \\
\hline \multirow[t]{2}{*}{ propositional } & epistemic & nil & $0(0 \%)$ & nil & $0 \quad(0 \%)$ \\
\hline & evidential & nil & $0(0 \%)$ & nil & $0 \quad(0 \%)$ \\
\hline \multirow[t]{6}{*}{ event } & deontic & 必须(bixu) & $4(27 \%)$ & shall & $99(84.0 \%)$ \\
\hline & & 应当 (yingdang) & $5(33 \%)$ & will & $1(0.8 \%)$ \\
\hline & & 不得(bude) & $3(20 \%)$ & may & $18(15.2 \%)$ \\
\hline & & 不能(buneng) & $1(7 \%)$ & & \\
\hline & & 可以 $(k e y i)$ & $2(13 \%)$ & & \\
\hline & dynamic & nil & $0(0 \%)$ & nil & $0(0 \%)$ \\
\hline Total & & & $15(100 \%)$ & & $118(100 \%)$ \\
\hline
\end{tabular}

$\mathrm{PRC}=$ PRC Constitution; US = U.S. Constitution; Freq = Frequency

The data show that there is event modality in the two constitutions. However, there is no propositional modality since it involves the speakers' personal judgment. Table 3 shows that the PRC text has only 15 modal verbs, a much lower number compared to that in the US text. Among these modal verbs, “必须(bixu); 应当(yingdang); 不得(bude); 不能(buneng)” are advanced level modals and “可以(keyi)" is a lower level modal. The US text does not have advanced modal verbs, as the modals "shall" and "will" in the US text belong to the intermediate level. See the following examples, where modality is italicised.

5) 第六十七条

(二) 制定和修改除应当由全国人民代表大会制定的法律以外的其他法律 ;

（三）在全国人民代表大会闭会期间，对全国人民代表大会制定的法律进行部分 补充和修改, 但是不得同该法律的基本原则相抵触;

（五）在全国人民代表大会闭会期间，审查和批准国民经济和社会发展计划、国 家预算在执行过程中所必须作的部分调整方案 ;

Translation (Article 67 (2) to enact and amend laws, with the exception of those which should be enacted by the National People's Congress; (3) to partially supplement and amend, when the National People's Congress is not in session, laws enacted by the National People's Congress, provided that the basic principles of these laws are not contravened; (5) to review and approve, when the National People's Congress is not in session, partial 
adjustments to the plan for national economic and social development or to the State budget that prove necessary in the course of their implementation;)

6) Section 2 - The House

No Person shall be a Representative who shall not have attained to the Age of twenty five Years, and been seven Years a Citizen of the United States, and who shall not, when elected, be an Inhabitant of that State in which he shall be chosen.

The modality in the above examples is event modality, which belongs to deontic modality. The two constitutions lack dynamic modality since it relates to individual's willingness and refers to personal inner modality. The stronger the compulsion for making an event to take place, the more certain a speaker can be towards the actuality of that event. Example 5 suggests that lawmakers of PRC tend to use advanced level verbs to highlight the country's authority. In example 6 , the modal verb "shall" belongs to the intermediate level, which shows the lawmakers' efforts to present their opinion positively through encouragement and guidance.

As the above examples suggest, the modals in the U.S. constitution are almost intermediate value, while the advanced value modals in the Chinese constitution account for a high proportion. Comparatively therefore, it can be suggested that writers of the Chinese constitution express more directly and strongly than writers of the U.S. constitution.

\section{Comparison of Thematic Structure}

As the means of carrying the basic message of the clause, thematic structure embodies a kind of interpersonal function. Writers who recognise the value of thematic structure can draw the readers in by presenting the prominent information and by clearly setting out the topic the context they will respond to. The arrangement of thematic structure invests the issue with significance and invites collusion with readers. The thematic structure is an important feature in systemic functional grammar. The theme is the first constituent, which denotes the starting point of what is going to be discussed. The thematic structure is an important strategy for capturing readers' attention. It may be the case that writers express their awareness of the presence of the readers in the deployment of thematic structure.

Halliday (1973) proposed a marked theme and unmarked theme within clauses. A clause is a grammatical unit, which constitutes a group of words consisting of a subject and a verb. The theme occurs first in an English clause. By showing directly what a clause contains, a marked theme has an initial presentation such as "We could eat those berries!" An unmarked theme does not have "we" in it, presenting as "Could eat those berries." An unmarked theme consists of the process only. The unmarked theme can be an explanation of a person who does something in a clause. For example, "Lucy hit her brother on the head." The theme in this case is that who hits her brother.

Table 4 shows the frequency of meta-discourse markers relating to thematic structure in the texts in the PRC Constitution and the U.S. Constitution.

Table 4. Thematic Structure in the PRC Constitution and the U.S. Constitution

\begin{tabular}{lcccr}
\hline \multirow{2}{*}{ Type of Theme } & PRC (chapter three) & \multicolumn{3}{c}{ US (article one) } \\
\cline { 2 - 5 } & Freq of MD & $\%$ & Freq of MD & $\%$ \\
\hline Marked Theme & 10 & 22 & 14 & 19 \\
\hline Unmarked Theme & 35 & 78 & 60 & 81 \\
\hline Total & $\mathbf{4 5}$ & $\mathbf{1 0 0}$ & $\mathbf{7 4}$ & $\mathbf{1 0 0}$ \\
\hline
\end{tabular}

$\mathrm{PRC}=\mathrm{PRC}$ Constitution; US $=$ U.S. Constitution; $\mathrm{MD}=$ Meta-discourse

As evident in Table 4, the unmarked theme constitutes a major percentage in the two constitutions compared to the marked theme. The marked theme focuses on describing environmental factors such as conditions and time, with the clausal theme as its manifestation (see examples 7, 8, and 9). Examples 7, 8, and 9 suggest that the selection of thematic structure in the two constitutions is consistent, emphasising the conditions of a special situation， such as在全国人民代表大会闭会期间 (when the National People's Congress is not in session),

在不同宪法、法律、行政法规相抵触的前提下

(which must not contravene the Constitution and other laws and administrative regulations), and if Vacancies happen by Resignation, or otherwise.

7) 第九十二条

国务院对全国人民代表大会负责并报告工作；在全国人民代表大会闭会期间，对全国人民代表大会常务委 员会负责并报告工作。

Translation (Article 92 The State Council is responsible and reports on its work to the National People's Congress or, when the National People's Congress is not in session, to its Standing Committee.) 
8) 第一百条

省、直辖市的人民代表大会和它们的常务委员会, 在不同宪法、法律、行政法规相抵触的前提下, 可以制 定地方性法规，报全国人民代表大会常务委员会备案。

Translation (Article 100 The people's congresses of provinces, and municipalities directly under the Central Government, and their standing committees may adopt local regulations, which must not contravene the Constitution and other laws and administrative regulations, and they shall report such local regulations to the Standing Committee of the National People's Congress for the record.)

9) Section 3 - The Senate

and if Vacancies happen by Resignation, or otherwise, during the Recess of the Legislature of any State, the Executive thereof may make temporary Appointments until the next Meeting of the Legislature, which shall then fill such Vacancies

The preference for the unmarked theme proves that the two constitutions tend to put the more important information first and emphasise clarity, which embodies a sense of systematicity. The data in Table 4 indicate that the two constitutions are characteristically precise.

\section{Comparison of Information Structure}

Information structure describes the way in which information is packaged within a sentence. The basic notions of information structure are focus, givenness, and topic, as well as their complementary notions of background, newness, and comment, respectively. Information structure represents an interpersonal function by signalling writers' attitude towards the given information or new information. The subjective estimation and layout of information transmit writers' stance, attitude, and relationship to the context.

This study describes information structure from the perspective of voice, which is also a branch of information structure. Table 5 shows the results of the analysis of the PRC text and the US text on type of voice.

Table 5. Voice in the PRC Constitution and the U.S. Constitution

\begin{tabular}{lcccc}
\hline \multirow{2}{*}{ Type of Voice } & \multicolumn{2}{c}{ PRC (chapter three) } & US (article one) & \\
\cline { 2 - 5 } & Freq of MD & $\%$ & Freq of MD & $\%$ \\
\hline Active Voice & 47 & 76 & 73 & 62 \\
\hline Passive Voice & 15 & 24 & 45 & 38 \\
\hline Total & $\mathbf{6 2}$ & $\mathbf{1 0 0}$ & $\mathbf{1 1 8}$ & $\mathbf{1 0 0}$ \\
\hline
\end{tabular}

$\mathrm{PRC}=$ PRC Constitution; US $=$ U.S. Constitution; $\mathrm{MD}=$ Meta-discourse; Freq $=$ Frequency

The data in Table 5 suggest that the U.S. constitution generally has a higher frequency of active and passive voice than the PRC constitution. The frequency of occurrence of the two types of voice also shows that both the PRC and the U.S. constitutions make greater use of active voice to emphasise authority.

\section{Hypotaxis and Parataxis}

The structure of hypotaxis and parataxis reflects that a sentence not only conveys a logical and semantic order, but also grounds the writer's stance of information. The use of hypotaxis and parataxis in a text conveys the writer's purposes. For hypotaxis, the order of information is an interpersonal feature, a way of suggesting which one is more important. Meanwhile, in parataxis, the writer's choices are obvious that the parallel sentences are of equal importance.

The use of hypotaxis and parataxis is another typical feature in the implicit meta-discourse pattern. Table 6 shows the results of analysis of hypotaxis and parataxis in the two texts that were analysed.

Table 6. Hypotaxis and parataxis in the PRC Constitution and the U.S. Constitution

\begin{tabular}{|c|c|c|c|c|}
\hline \multirow{2}{*}{ Type of Voice } & \multicolumn{2}{|c|}{ PRC (chapter three) } & \multicolumn{2}{|c|}{ US (article one) } \\
\hline & Freq of MD & $\%$ & Freq of MD & $\%$ \\
\hline Hypotaxis & 11 & 25 & 11 & 37 \\
\hline Parataxis & 33 & 75 & 19 & 63 \\
\hline Total & 44 & 100 & 30 & 100 \\
\hline
\end{tabular}

$\mathrm{PRC}=$ PRC Constitution; US= U.S. Constitution; $\mathrm{MD}=$ Meta-discourse; Freq $=$ Frequency

Hypotaxis and parataxis indicate the writer's affective attitude as illustrated in the following examples.

Examples 10 and 11 are both assuming extraordinary circumstances that an election cannot be accomplished. The structure of hypotaxis “如果...由....”(if...then...) displays the writer's evaluation of the importance of information rather than affecting the propositional value. Writers believe that the solution of the national people's congress election is the key information, while the exceptional circumstance is the secondary message. The elucidation is likewise used in example 11 from the U.S. constitution, "the Chief Justice shall 
preside," and no Person shall be convicted" are the main information, and the condition is less important.

In examples 12 and 13, the former provision and the latter in the two examples are parataxis. The

10) 第六十条

全国人民代表大会任期届满的两个月以前, 全国人民代表大会常务委员会必 须完成下届全国人民代表大会代表的选举。如果遇到不能进行选举的非常情

况, 由全国人民代表大会常务委员会以全体组成人员的三分之二以上的多数通

过，可以推迟选举，延长本届全国人民代表大会的任期。

Translation (Article 60 The Standing Committee of the National People's Congress must ensure the completion of the election of deputies to the succeeding National People's Congress two months prior to the expiration of the term of office of the current National People's Congress. Should extraordinary circumstances prevent such an election, it may be postponed and the term of office of the current National People's Congress extended by the decision of a vote of more than two-thirds of all those on the Standing Committee of the current National People's Congress. The election of deputies to the succeeding National People's Congress must be completed within one year after the termination of such extraordinary circumstances.)

11) Section 3 - The Senate

The Senate shall have the sole Power to try all Impeachments. When sitting for that Purpose, they shall be on Oath or Affirmation. When the President of the United States is tried, the Chief Justice shall preside: And no Person shall be convicted without the Concurrence of two thirds of the Members present.

12) 第五十九条 全国人民代表大会代表的选举由全国人民代表大会常务委员会主持。全国人民 代表大会代表名额和代表产生办法由法律规定。

Translation (Article 59 Election of deputies to the National People's Congress is conducted by the Standing Committee of the National People's Congress.

The number of deputies to the National People's Congress and the procedure of their election are prescribed by law.)

13) The House of Representatives shall choose their Speaker and other Officers; and shall have the sole Power of Impeachment.

\section{Organisation of Discourse}

Ädel (2006) stated that "meta-discourse can be in many different forms, ranging from morphemes, single word forms, phrases, and clauses, to strings of sentences, the organisation of text" (p. 2). With regard to the organisation of the text, Kumpf (2000) suggested that it can be construed as "visual metadiscourse." This is because the organisation of a text reflects how the writer organises and arranges the text, presenting his or her personal purpose. The organisation of a text also has interpersonal function, involving the writers' understanding of context and readers. Essentially, the organisation of a text is related to the writers' purpose of communication.

The analysis of implicit meta-discourse in the current study shows that the organisation of discourse in the two texts extracted from the PRC constitution and the U.S. constitution is similar and is characteristic of law rhetoric. There are two main reasons for the preference for such organisation of text. Firstly, it is helpful for readers or law enforcement to quote the discourse procedural items. Secondly, the characteristic of solemnity and stateliness can be salient through the organisation of the text.

The comparison of the use of implicit interpersonal meta-discourse in the two constitutions essentially shows that there are similarities and differences. They are similar in terms of the use of declarative in the mood, deontic modals in modality, the proportion of marked theme and unmarked theme, and the organisation of discourse. They differ in the types of voice in the information structure.

\section{CONCLUSION}

The study firstly reveals that there is implicit interpersonal meta-discourse in the two constitutions. Secondly, there are similarities and differences in the use of implicit meta-discourse in both constitutions. Moreover, the grammatical types of mood, modality, thematic, information structure, hypotaxis, and parataxis, and organisation of discourse reveal the implicit interpersonal metadiscoursal function in both texts.

The frequencies of interpersonal meta-discourse essentially distinguish the use of meta-discourse in the two constitutions but not interpersonal grammatical meta-discourse categories. In terms of similarity, the findings suggest that both texts make significant use of declarative in mood, deontic modals in modality, marked theme and unmarked theme, showing the writer's choice of information. More importantly, the organisation of discourse in 
the two texts is similar, which is characteristic of legal discourse. The findings also show that the two constitutions take different types of voice in the information structure. The U.S. constitution makes greater use of hypothesis than the PRC constitution which may be due to the different political systems of the two countries.

Within the bigger context of language discourse, the current study found that legal discourse is distinctive in the use of implicit interpersonal meta-discourse, particularly in the way writers intrude into the discourse implicitly. Grammatical forms of meta-discourse, which allow the writer to implicitly engage in the context, are key features of legal discourse. So, although legal discourse is objective and impersonal, this study reveals that there exists meta-discourse in the legal discourse.

Studies on implicit meta-discourse in English and Chinese are rare, so the current findings on the grammatical meta-discourse used in the two constitutions provides new knowledge and the possibility to further explore how writers respond to their imagined readers and interactions between writers and readers in legal discourse.

Last but not least, the present study has focused on legal discourse, limited to one section in the Chinese and American constitutions. Nonetheless, the findings foreground new knowledge on the use of implicit personal metadiscourse in legal discourse. This information is crucial for lawmakers, contributes to the teaching and learning of legal discourse, and sheds new light on the area of grammatical meta-discourse.

\section{ACKNOWLEDGMENTS}

The authors would like to thank the Institute of Postgraduate Studies of Universiti Sains Malaysia for the postgraduate fellowship award, which helped to fund this research.

\section{REFERENCES}

Ädel, A. (2006). Meta-discourse in L1 and L2 English. Amsterdam/Philadelphia: John Benjamins.

Alyousef, H.S. (2015). An investigation of metadiscourse features in international postgraduate business students' texts: The use of interactive and interactional markers in tertiary multimodal finance texts. Sage Open, 5(4), 1-10.

Beauvais, P. (1989). A speech-act theory of metadiscourse. Written Communication, 6(1), 1130.

Bell, R.T. (1991). Translation and translating: Theory and practice. New York: Longman Inc.
Chafe, W.L., \& Nicholas, J. (1986). Evidentiality: The linguistic coding of epistemology. Norwood: Ablex.

Connor, U.M., \& Moreno, A.I. (2005). Tertium comparationis: a vital component in contrastive rhetoric research. In P. Bruthiaux, D. Atkinson, W. G. Eggington, W. Grabe, \& V. Ramanathan (Eds.), Directions in applied linguistics: Essays in honor of Robert B. Kaplan (pp. 153-164). Clevedon, England: Multilingual Matters.

Crismore, A. (1983). Metadiscourse: What it is and how it is used in school and non-school social science texts. Urbana-Champaign: University of Illinois.

Crismore, A. (1989). Talking with readers: Metadiscourse as rhetorical act. New York: Peter Lang Press.

Crismore, A. \& Farnsworth, R. (1990). Metadiscourse in popular and professional science discourse. In W. Nash (Ed.), The writing scholar: Studies in academic discourse (pp. 118-36). Newbury Park, CA: Sage.

Dahl, T. (2004). Textual meta-discourse in research articles: a marker of national culture or of academic discipline?. Journal of Pragmatics, 36, 1807-1825.

Del, S.R. \& Milagros, M. (2011). A pragmatic approach to the macro-structure and metadiscoursal features of research article introductions in the field of agricultural sciences. English for Specific Purposes, 3, 258 271.

Halliday, M.A.K. (1973). Explorations in the functions of language. NY: Elsevier-NorthHolland.

Halliday, M.A.K. (2004). Introduction to functional grammar. London: Arnold.

Halliday, M.A.K. (1976). System and function in Language. London: Oxford University Press.

Halliday, M.A.K., \& Matthiessen, M.I.M. (2004). Halliday's introduction to functional grammar. London and New York: Routledge.

Harris, Z. (1959). The transformational model of language structure. Anthropol. Linguist, 1 (1), 27-29.

Hewings, M. (2006). Introduction. In Hewings (Ed.), Academic writing in context (pp. 9-16). London: Continuum.

Hopper, R. (1981). The taken for granted. Human Communications Research, 7, 195-211.

Hyland, K. (2000). Disciplinary discourses: Social interactions in academic writing. London: Longman.

Hyland, K. (2008). Meta-discourse. Beijing: Foreign Language Teaching and Research Press.

Hyland, K. (2017). Meta-discourse: What is it and where is it going?. Journal of Pragmatics, 113, 16-29. 
Jiang, F.K., \& Hyland, K. (2016). Nouns and academic interactions: A neglected feature of meta-discourse. Applied Linguistics, 1-25.

Kawase, T. (2015). Metadiscourse in the introductions of $\mathrm{PhD}$ theses and research articles. Journal of English for Academic Purposes, 20, 114-124.

Kumpf, E. P. (2000). Visual metadiscourse: Designing the considerate text. Technical Communication Quarterly, 9(4), 401- 24.

McGrath, L., \& Kuteeva, M. (2012). Stance and engagement in pure mathematics research articles: Linking discourse features to disciplinary practices. English for Specific Purposes, 31, 161-173.

Nagy, W. (1988). Personal communication. Urbana Champaign: University of Illinois.

Palmer, F. R. (2001). Mood and modality. Cambridge: CUP.

Peacock, M. (2002). Communicative moves in the discussion section of research articles. System, 30(4), 479-497.

Peng, X.W. (2000). A comprehensive comparison between English and Chinese texts. Shanghai: Shanghai Foreign Language Education Press.

Reza, A. (2002). Interpersonal meta-discourse: an indicator of interaction and identity. Discourse Studies, 4, 139.

Sangster, R. (1987). Personal communication. Bloomington: Indiana University.

The National People's Congress. (1982). People's Daily Online. Retrieved from http://www.people.com.cn/GB/shehui/1060/23 91834.html
Tyler, A. (1988). Personal communication. Gainesville: University of Florida.

United States Senate. (1992). Amendments to the Constitution of the United States of America. The Constitution of the United States of America: Analysis and Interpretation. U.S. Government Printing Office. Retrieved from https://www.gpo.gov/fdsys/pkg/GPO-CONAN1992/html/GPO-CONAN-1992-8.htm

Vande Kopple, W. (1985). Some exploratory discourse on meta-discourse. College Composition and Communication, 36, 82-93.

Vande Kopple, W. (2012). The importance of studying meta-discourse. Applied Research in English, 1(2), 37-44.

Vassileva, I. (2000). Who is the author?: A contrastive analysis of authorial presence in English, German, French and Bulgarian academic discourse. Sankt Augustin: AsgardVerlag.

Yang, A., Zheng, S., \& Ge, G. (2015). Epistemic modality in English-medium medical research articles: A systemic functional perspective. English for Specific Purposes, 38, 1-10.

Zhang, M. (2016). A multidimensional analysis of metadiscourse markers across written registers. Discourse Studies, 18(2), 204-222.

Zhang, Y. H. (2013). An initial exploration of grammatical meta-discourse. Hubei Social Sciences, 1, 133-136.

Zhang, Y. H. (2014). A Study of meta-discourse in Chinese legal texts (Unpublished Doctoral Dissertation). Central China Normal University, Wuhan. 


\section{Appendix}

\begin{tabular}{|c|c|c|c|c|c|}
\hline $\begin{array}{l}\text { The advanced } \\
\text { modals in } \\
\text { Chinese }\end{array}$ & $\begin{array}{l}\text { English } \\
\text { Translations }\end{array}$ & $\begin{array}{l}\text { The } \\
\text { intermediate } \\
\text { modals in } \\
\text { Chinese }\end{array}$ & $\begin{array}{l}\text { English } \\
\text { Translations }\end{array}$ & $\begin{array}{l}\text { The lower } \\
\text { modals in } \\
\text { Chinese }\end{array}$ & $\begin{array}{l}\text { English } \\
\text { Translations }\end{array}$ \\
\hline $\begin{array}{l}\text { 应当 } \\
\text { (yingdang) }\end{array}$ & must; ought to & 愿意 (yuanyi) & will; would & 可能 (keneng) & may; might \\
\hline 应该(yinggai) & must & 想(xiang) & would & 会 $(h u i)$ & be allowed to \\
\hline 必须(bixu) & must & 希望 (xiwang) & will & 可以 (keyi) & could \\
\hline 务必(wubi) & must & 肯 $(k e n)$ & could & 能 (neng) & can \\
\hline 应 (ying) & must & 敢(gan) & shall; should & $\begin{array}{l}\text { 能够 } \\
\text { (nenggou) }\end{array}$ & can \\
\hline 要 $(y a o)$ & must & 愿(yuan) & will; would & 不会(buhui) & may not \\
\hline 须要 (xuyao) & must; ought to & $\begin{array}{l}\text { 不愿意 } \\
\text { (buyuanyi) }\end{array}$ & $\begin{array}{l}\text { will not; } \\
\text { would not }\end{array}$ & 不必 (bubi) & do not have to \\
\hline $\begin{array}{l}\text { 不可能 } \\
\text { (bukeneng) }\end{array}$ & must not & $\begin{array}{l}\text { 不情愿 } \\
\text { (buqingyuan) }\end{array}$ & $\begin{array}{l}\text { will not; } \\
\text { would not }\end{array}$ & $\begin{array}{l}\text { 可能不 } \\
\text { (kenengbu) }\end{array}$ & might not \\
\hline 不可(buke) & cannot; must not & 不想(buxiang) & will not & 无须 (wuxu) & need not \\
\hline 不能(buneng) & $\begin{array}{l}\text { cannot; should } \\
\text { not; must not }\end{array}$ & 不肯(buken) & $\begin{array}{l}\text { will not; shall } \\
\text { not }\end{array}$ & 不须(buxu) & need not \\
\hline 不得 (bude) & must not & & & & \\
\hline 不该(bugai) & ought not to & & & & \\
\hline
\end{tabular}

